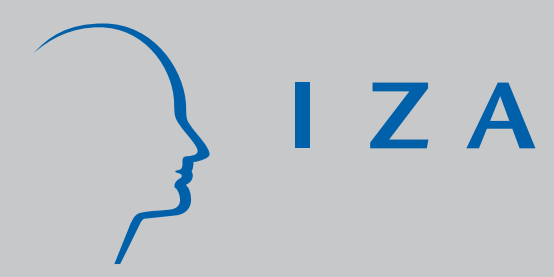

IZADP No. 4066

Changing Fertility Preferences One Migrant at a Time: The Impact of Remittances on the Fertility Rate

George Naufal

Carlos Vargas-Silva

March 2009 


\title{
Changing Fertility Preferences One Migrant at a Time: The Impact of Remittances on the Fertility Rate
}

\author{
George Naufal \\ American University of Sharjah \\ and IZA \\ Carlos Vargas-Silva \\ Sam Houston State University
}

Discussion Paper No. 4066

March 2009

\author{
IZA \\ P.O. Box 7240 \\ 53072 Bonn \\ Germany \\ Phone: +49-228-3894-0 \\ Fax: +49-228-3894-180 \\ E-mail: iza@iza.org
}

\begin{abstract}
Any opinions expressed here are those of the author(s) and not those of IZA. Research published in this series may include views on policy, but the institute itself takes no institutional policy positions.

The Institute for the Study of Labor (IZA) in Bonn is a local and virtual international research center and a place of communication between science, politics and business. IZA is an independent nonprofit organization supported by Deutsche Post Foundation. The center is associated with the University of Bonn and offers a stimulating research environment through its international network, workshops and conferences, data service, project support, research visits and doctoral program. IZA engages in (i) original and internationally competitive research in all fields of labor economics, (ii) development of policy concepts, and (iii) dissemination of research results and concepts to the interested public.
\end{abstract}

IZA Discussion Papers often represent preliminary work and are circulated to encourage discussion. Citation of such a paper should account for its provisional character. A revised version may be available directly from the author. 


\section{ABSTRACT}

\section{Changing Fertility Preferences One Migrant at a Time: The Impact of Remittances on the Fertility Rate}

In this article we study the relationship between workers' remittances and fertility rate of the remittance receiving country. We identify two main channels by which remittances transfers affect fertility. First, migrants may adopt and later transmit to the household the ideas, values and attitudes predominant in the host country. Arguably, migrants with more attachment to the household would be more inclined to remit money home. Therefore, remittances can be seen as a proxy for the level of social norms (including fertility preferences) that is transmitted from the migrant to the household. Second, previous studies have shown that remittances money is often used for health services and educational expenses, factors that may ultimately decrease fertility rates. Using panel data for several countries we find a negative relationship between remittances and the fertility rate. The relationship is robust for a subsample of Latin American and African countries, but not for a sub-sample of Asian countries. In addition to finding evidence on the transfer of social norms from migrants to the home country, the paper also confirms that several socio-economic factors such as female labor force participation, percent of the population in rural areas and GDP per capita affect fertility rates.

JEL Classification: F22, F24, J13, Q56

Keywords: remittances, fertility rate, panel data, Latin America, Africa, Asia

Corresponding author:

George Naufal

American University of Sharjah

School of Business and Management

P.O. Box 26666

Sharjah

United Arab Emirates

E-mail: gnaufal@aus.edu 


\section{Introduction}

The stock of international migrants has grown dramatically in recent years. In 2000 the International Organization for Migration (IOM) estimated that there were 176 million international migrants, but this number increased to 191 million by 2006 (International Organization for Migration, 2006). These figures indicate a 10 percent increase in the stock of international migrants in just six years. Moreover, added together the present number of international migrants would represent one of the most populous countries in the world. This increase in the stock of international migrants, in addition to the reduction of fees for transferring money across countries have spurred an increase in the international flow of migrants' remittances. The latest estimates from the World Bank value global remittance flows to be around US\$ 318 billion (Migration and Remittances, Factbook 2008).

While migration rates have increased, fertility rates have declined in most countries. In some developed countries (e.g. OECD countries) fertility rates have declined to levels below those needed to secure generational replacement (Sleebos, 2003). This fact has encouraged many governments in industrialized nations to develop policies aimed at promoting and facilitating childbearing. Meanwhile, in least developed countries, high population growth is still considered to be one of the obstacles to economic growth. Although women in the developing world tend to have fewer children than before, the fertility rates remain high when compared to developed countries.

Are migration rates and fertility levels related? The previous literature suggests that these two variables may be linked. In fact, there is a vast literature on migrant's fertility rates. Most studies fall into one of two categories. First, earlier studies argue that 
migrants reflect fertility preferences dominant in the home country or region. Therefore, convergence towards fertility levels of the host country occurs only in the second generation. Some recent studies even argue further that the second generation is still strongly influenced by the fertility preferences of the parent's home country (Fernandez and Fogli, 2009). Other types of studies conclude that with time the fertility behavior of migrant households comes to resemble the fertility behavior of the households in the host country. Of course we expect to find that, in any case, migrant households have predominantly low levels of fertility immediately following migration, due to the disruptive factors associated with the migration process (Kulu, 2003).

While most of this literature has focused on the fertility behavior of the migrants we may ask: What happens to the fertility behavior of those family members and friends that stayed behind in the host country? Fargues (2007) argues that migrants adopt and later transmit to their home countries the ideas about fertility that prevail in the host country. Therefore, for countries with a large number of migrants we should see a convergence of fertility rates between the home and host countries. For each developing country the convergence is going to be different because the selection of destination countries by domestic migrants is different. Furthermore, migrants in some destination countries may have a stronger connection to the home country than migrants in other host country destinations. It is expected that the stronger the bond between migrants and the home country, the larger the flow of social norms from the host to the home country and therefore the faster the convergence of fertility rates should be between the countries.

Unfortunately, time series data on the distribution of migrants in different host countries is often missing for many countries. Moreover, even if we have the number of 
migrants from one home country in each host country over time, it would still be difficult to measure the attachment of those migrants to family and friends back home. One way to measure the strength of the relationship between migrants and the families back home is to look at the flow of workers' remittances. Arguably, migrants with more attachment to the home country would be more inclined to remit money home. That is, monetary remittances can be a measure of the so-called social remittances. Levitt (1998) describes social remittances as the ideas and norms of behavior that flow from host to home countries through migrants.

Hence, it is not just money what flows between the host and home countries. Migrants also send behavioral expectations back home. We argue that monetary sums reflect the strength of the bond between the migrant and the household and can be a good indicator of the level of social remittances. If this is the case, given that remittances reflect the attachment of migrants to the household, and that most migration takes place from high fertility countries to low fertility countries, we should expect a negative relationship between remittances and the fertility rate of the home country.

This idea applies regardless of the reason for remitting. There has been considerable debate in the remittances literature about the migrant's main motivations to send money back home. Several studies argue that migrants are altruistic individuals that care about the household's well-being and remit to improve the household's living standards. Other studies argue that there are self-interest motives for remitting such as investments in the home country or the potential gratitude of the household when returning home. In both scenarios remittances reflect an attachment of the migrant to the home country. 
In this paper, we investigate the effects of remittances on the fertility rate. In addition to being a reflection of the link between migration and fertility there are several other reasons that lead us to think that remittances and the fertility rate might be related. First, the receiving household (especially rural households) may view children as a substitute to a strong social security system and therefore sees having more kids as an investment. The old theory of having kids as potential workers in the fields applies here where children are now seen as future potential remitters. Nevertheless, the previous literature suggests that an important portion of remittance money is spent on health services which could include contraception and other medicine that may ultimately decrease the fertility rate. Furthermore, there are several studies that support the notion that remittances may increase the education of children in the household. As Cleland (2003) argues, education persistently comes out as the most dominant predictor of demographic behavior. Therefore, the fact that remittances may impact home country education levels suggests yet another channel by which remittances may affect the fertility rate.

The significant amounts of remittance flows during the previous decades triggered a massive interest on these transfers among researchers. A large portion of the literature has focused on the determinants of these flows (e.g. El-Sakka, M. and McNabb, R. (1999), Vargas-Silva (2008)). Other studies have focused on the economic consequences of these monetary flows whether on the macroeconomic side (Amuedo-Dorantes and Pozo (2004), Chami et. al. (2005)) or at the household level (Amuedo-Dorantes and Pozo (2006)). However, there is an absence of studies focusing on the impact of remittances 
transfers on the fertility rate of receiving countries. In this paper our intention is to fill this lacuna.

\section{Theoretical Background and Literature Review}

In this section, we explain further the intuition behind the relation between the fertility rate and remittance transfers and discuss the relevant literature. Letting $F R$ represent the total fertility rate in the receiving country, letting $R$ denote workers' remittances and letting $X$ be a vector of other determinants of fertility rate, we can write our equation of interest as:

$$
F R=f(R ; X)
$$

Remittances define the strength of the relationship between migrants and the remaining household members. The greater remittances are, the stronger the bond is and the larger the impact of migrants on the remaining members of the household. This impact includes, among other things, the decision to have children and the optimal number of children to have. The flow of ideas between migrants, mostly living in lower fertility rate countries, is expected to push the fertility of remaining household members closer to the fertility levels prevalent in the host country.

Furthermore, as we mentioned in the introduction remittance transfers are often used for health expenses which may include contraception and other medicine that reduces the fertility rate. For instance, Adams (2005), using data for Guatemala, finds that the remittance receiving households spend more on health than do other households. For the case of Mexico, Amuedo-Dorantes et al. (2007) and Valero-Gil (2008) find that often remittances are specifically targeted towards household's health expenditures. 
There are also several studies that support the notion that remittances may increase the education of children in the household. Receiving remittances relaxes the budget constraint of the household, allowing the household to afford sending children to school. Also, there may be a reduced need for child labor as a result of the additional income. One additional possibility is that senders of remittances explicitly want the children in the household to attend school. If we see remittances as an intergenerational process, the migrants may plan to retire in the home country and these children will be supporting them financially at an older age. One specific example can be found in the results obtained by Edwards and Ureta (2003). Using data for El Salvador, they find that remittances affect school retention positively. The impact of remittances on school retention was larger than the impact of other sources of household income. Other example of papers finding similar results includes Lu and Treiman (2007) for blacks in South Africa.

On the other hand, remittances may be considered a source of non-labor income. Dissimilarly to an increase in the wage rate (especially the female wage rate) that increases the opportunity cost of forgoing labor and investing time in childbearing activities, remittances may encourage the demand for children. If children are normal goods the increase in non-labor income may result in an increasing demand for children.

The main objective of this paper is to empirically examine the relationship between remittances and fertility rate in the receiving country. A couple of papers have discussed ideas similar to ours. For instance, Fargues (2007) uses time series data to document a negative correlation between remittances and births in Morocco and Turkey and a positive one in Egypt. The author attributes this correlation to the flow of ideas and 
attitudes from migrants towards their receiving counterparts. While remittances to Egypt come primarily from the Persian Gulf (countries less advanced in the demographic transition), remittances to Morocco and Turkey come mainly from Europe (that is, from countries more advanced in the demographic transition). While the ideas put forward in Fargues (2007) are interesting and innovative, the empirical analysis is conducted using simple correlation coefficients. These correlation coefficients are simple bi-variate statistics that do no reflect causation and that do not allow for the inclusion of additional factors in the estimation. Moreover, we argue that the treatment of remittances as just a reflection of the link between migrants and households is overly simplistic given that remittances have other important implications for household behavior.

Beine et al. (2008) study the link between international migration and fertility focusing on the impact of norms from the host country on home country fertility rates. They are able to find evidence of a strong transfer of fertility norms from migrants to their host countries. In their paper they see remittances as a source of non-labor income or a method of transfers in old age for the household. We argue that, in addition to representing a source of non-labor income, remittances are a useful measure of the strength of the relationship between the household and the migrant. Moreover, while their paper controls for the volume of remittances that is not the main focus of their paper. In this paper we focus on the role of remittances in the transmission of ideas from migrants to the household.

In order to be successful in our efforts we must control for a series of additional factors. In specific, we control for the percentage of the population living in rural areas, the female labor force participation rate, income per capita, the percentage of population 
as migrants and the fertility rate in the top five destinations of migrants from each home country (weighted average). ${ }^{1}$

The fertility rate in rural areas is higher than the fertility rate in urban areas which suggests that the percentage of population living in rural areas and fertility rate are positively related (United Nations, 1986). We expect a negative relationship between the female labor force participation rate and fertility rate. Put simple, the more females participate in the labor force the higher their opportunity cost and therefore the lower the fertility rates (Yamada and Yamada, 1984). Higher income per capita typically leads to lower fertility rates so we anticipate a negative relationship between this variable and the number of children per family (Docquier (2004), Jones and Tertilt (2008)). The direction of the relationship between the migration stock as percentage of the population and fertility is not completely clear. Migrants in general move from higher to lower fertility rate countries and it takes some time to adjust to the fertility levels of the host country. However, the act of migration implies a disruptive process that temporarily decreases fertility. Finally, higher fertility rates at the top 5 destinations of migrants from a certain country should encourage fertility.

\section{Data and Methodology}

There are several important issues concerning aggregate remittances data. First, countries tend to use different rules with regard as to what type of transactions should be classified as remittance transfers. Second, there may be an important share of remittances that are sent through informal channels, making it sometimes difficult for the government to track these flows. In order to alleviate these concerns we use a broad measure of remittances

\footnotetext{
${ }^{1}$ We wanted to control for education through literacy rates but due to data availability we could not include this variable.
} 
from the World Development Indicators. In specific, remittances are defined as the numbers reported under the category worker's remittances and compensation of employees. This measure is more inclusive than the simple remittances series reported in the balance of payments. ${ }^{2}$ In the regressions we use the logarithm of the total value of these transfers.

In total we have an unbalanced panel of 59 countries with data for most countries for the period 1980 to 2005 (there are a few countries for which the available data starts from 1985) ${ }^{3}$. The World Bank records the fertility rate variable for each country following their last census. For that reason, the fertility rate measure is only available in increments of five years. We use the total fertility rate, which measures the number of children that would be born to a woman if she were to live to the end of her childbearing years and bear children in accordance with customary age-specific fertility rates.

The other variables included in the estimation are the percentage of the population living in rural areas, the female labor force participation rate, the logarithm of income per

\footnotetext{
${ }^{2}$ When recommending the use a broad measure of remittances, the World Bank Remittances Factbook (2008) argues that 'Workers' remittances, as defined in the IMF Balance of Payments manual, are current private transfers from migrant workers who are considered residents of the host country to recipients in their country of origin. If the migrants live in the host country for a year or longer, they are considered residents, regardless of their immigration status. If the migrants have lived in the host country for less than a year, their entire income in the host country should be classified as compensation of employees. Although the residence guideline in the manual is clear, this rule is often not followed for various reasons. Many countries compile data based on the citizenship of the migrant worker rather than on their residency status. Further, data are shown entirely as either compensation of employees or as worker remittances, although they should be split between the two categories if the guidelines were correctly followed. The distinction between these two categories appears to be entirely arbitrary."

3 The list of countries includes: Latin America: Argentina, Belize, Bolivia, Brazil, Colombia, Costa Rica, Dominican Republic, Ecuador, Guatemala, Honduras, Mexico, Venezuela, El Salvador, Panama and Suriname. Asia: Bangladesh, China, Cyprus, India, Indonesia, Jordan, Korea, Lao PDR, Malaysia, Oman, Pakistan, Papua New Guinea, Philippines, Sri Lanka, Syrian Arab Republic, Thailand and Turkey. Africa: Algeria, Benin, Botswana, Burkina Faso, Cameroun, Cape Verde, Comoros, Ivory Coast, Egypt, Ethiopia, Gambia, Ghana, Kenya, Madagascar, Mali, Mauritania, Mozambique, Rwanda, Senegal, Sudan, Swaziland, Togo, Tunisia, Lesotho, Niger, Nigeria, Morocco.
} 
capita, the percentage of population that are migrants and the average fertility rate of the top 5 destinations of migrants from each country. The source of the first four variables, as well as the fertility rate variable, is also the World Development Indicators from the World Bank online databases. The average host fertility rate is estimated using the measures of fertility from the World Development Indicators and the information on migrant's destinations from Parsons et al. (2007). The average host fertility rate is constructed as a weighted average where the relative importance of each of the host country fertility rates is provided by the relative stock of migrants from the home country in that host country. ${ }^{4}$ Descriptive statistics of all the variables included in the estimation are provided in the appendix.

We conduct a series of estimations in order to ensure the robustness of our results. First, we conduct an ordinary least squares (OLS) estimation using the full sample of countries. Next, we conduct an estimation using the full sample and including dummy variables for region of the world. Third, we conduct an estimation using the full sample and fixed effects to control for country specific heterogeneity. Finally, we conduct an instrumental variable estimation in order to address potential issues of endogenity.

We are also interested in measuring possible regional differences in the relationship between remittances and the fertility rate. Different regions of the world are in different stages of the demographic transition and this may impact the relationship between remittances and fertility. Moreover, the selection of host countries by migrants also differs by region. Therefore, after conducting an estimation using all the countries in our sample we conduct separate estimations by region. Particularly, we have an

\footnotetext{
${ }^{4}$ The information on migrant's destinations in Parsons et al. (2007) is only provided for the year 2000. Hence, we have to assume that the migrant stock is constant over time.
} 
estimation using only Latin American countries (15 countries), one with only Asian countries (17 countries) and one with only African countries (27 countries). We conduct both, OLS and country-specific fixed effects estimations using the regional sub-samples.

Figure 1 shows the average fertility rate of the countries in our sample and the volume of remittances over time. As we can appreciate from the figure, for all regions, while remittances have been increasing overtime (especially since 1985), fertility rates have been decreasing. Let's also look at Table 1 in which we report correlation coefficients for remittances and the fertility rate. As Table 1 shows, for the full sample and for all the sub-samples, the correlation of remittances and fertility rates is negative. This is in general consistent with the results provided by Fargues (2007). However, as we mentioned above, in order to establish a relationship between remittances and fertility rates we need to include more variables in the estimation. Is this relationship going to hold once we control for other important determinants of fertility? In the following sections we use multiplicity of econometric approaches to answer this question.

\section{Results for the Full Sample}

We start our econometric analysis by showing the results if we include the 59 countries for which we have data in the estimation. The results from this exercise are reported in Table 2. In column 1 we present the results from OLS, in column 2 we present the results obtained using regional dummy variables, while in column 3 we report the results obtained including country specific fixed effects. The coefficients of the regressions are reported with robust standard errors in parenthesis.

Focusing first in column 1, notice that all the control variables have the desired sign. The fertility of the host countries has a positive impact on fertility rates. Hence, migration 
to countries with lower fertility rates decreases domestic fertility rates as we expected. The portion of the population living in rural areas has a positive effect on fertility. As the previous literature shows, for many countries fertility rates are much higher in rural than in urban areas. Also consistent with the previous literature GDP per capita and female labor force participation have a negative relationship with fertility. Finally, the migrant stock has a positive impact on fertility.

With regard to remittances we can appreciate that these flows have a negative impact on fertility levels. As we mentioned above, most migration takes place from countries with higher fertility rates to countries with lower fertility rates (in fact, $80 \%$ of the observations in our sample have a lower fertility than the host fertility). After sometime in the host country, the migrant adopts home country fertility norms and later he/she transmits those norms back to the host country. However, how much behavior gets transmitted depends on the strength of the relationship between the migrant and the family back home. We argue that remittance flows can be a good measure of the strength of that relationship. Additionally, remittances are often used for health and educational expenses, two factors that tend to lower fertility rates. Increase spending in health services may, among other things, decrease infant mortality a factor that has been showed previously to trigger a subsequent decline in fertility rates (Yamada, 1984). Increase educational levels may augment the knowledge about contraception and increase the opportunity cost of children.

Next we include regional dummy variables in the estimation. As McKibbin (2006) argues, there has been a global demographic transition from high to low population growth rates but at different rates in different regions. For instance, while population 
growth rates were higher for Latin America than for Asia in the 1950s and 1960s, population growth rates are now higher in Asia than in Latin America. Nevertheless, in both cases population growth rates have decreased dramatically during the last 50 years. Hence, it is important to estimate our results controlling for different regions of the world. In specific, we focus on three regions: Latin America, Asia and Africa.

The regressions with regional dummy variables are reported in column 2 of Table 2. The results are not affected by the inclusion of regional dummies. It is still the case that remittances, the average fertility of the main host country destinations, female labor force participation and GDP per capita have a negative impact on fertility rates, whereas the portion of population living in rural areas has a positive impact. It is interesting to note that both the dummy for Latin America and Asia are significant indicating the possibility of interesting dynamics across regions.

Still even using the regional dummy variables there may be some country specific heterogeneity left that we may want to control for and, therefore, we conduct fixed effects estimation. Those results are reported in column 3 of Table 2 . When analyzing the results from the fixed effects estimation we have to keep in mind that we only have 343 observations and 59 countries (or groups in the estimation). Including the fixed effects changes the results to some extent. First, GDP per capita and the migrant stock are not significant any longer. Moreover, the remittances coefficient while still negative is also not significant. On the other hand, the result regarding the fertility of the host countries, population in rural areas and female labor force participation do not seem to be affected by the inclusion of fixed effects. 
We want to explore further this difference in the results of the OLS estimation and the fixed effects estimation. One way to gain additional insights on this issue is to divide our sample in regions and conduct both types of estimations in each region. Furthermore, this division is going to allow us to compare the results in regions that, as we mentioned above, are in different stages of the demographic transition. As the regional dummies estimation showed there may be some interesting regional dynamics in fertility behavior. We conduct this regional estimation in the next section.

\section{Results for the Regional Samples}

Table 3 reports the results of the estimations when we limit our sample to countries in a certain region. In columns 1 and 2 we report the OLS and fixed effects results when we focus on Latin American countries only. It seems that for Latin America the results for remittances are consistent across estimations. In both cases, remittances seem to have a negative impact on the fertility rate. Interestingly, for the case of Latin America it seems that while in the OLS estimations the host country fertility rate has the expected sign, in the fixed effects estimation this variable turns negative. However, as discussed

previously, given the limited number of observations that we have in the estimation, we should be careful in interpreting the results from the fixed effects regression.

It also seems that the results for remittances are consistent for the African countries. In both cases remittances have a negative impact on the fertility rate and although the level of significance decreases somewhat in the fixed effects estimations, the coefficients are similar in size. Moreover, when we include the fixed effects it seems that only remittances, the fertility of the host countries and the portion of the population living in rural areas are significant determinants of fertility for these African countries. 
Nevertheless, as can be seen in columns 5 and 6, for the Asian sub-sample results change when we use different estimation methodologies. While in the OLS estimation we have the now familiar result of remittances having a negative impact on the fertility rate, this result turns around in the fixed effect estimations. It seems that when we take into account country specific heterogeneity the evidence on a negative impact of remittances on the fertility rate disappears for Asian countries. This is the only time in the previous nine regressions in which we get a positive coefficient for remittances. Therefore, we can say that our results are relatively robust for all regions, but for Asia. However, in order to explore more the robustness of our results we need to account for possible endogenous relationships between our variables. We do that in the next section by conducting an instrumental variable estimation.

\section{Instrumental Variable Estimation}

It is possible to argue that fertility rates may also affect the level of remittance transfers. That is, there maybe some reverse causality with respect to remittances and fertility rates. A bigger household means that more people are dependent on migrant's transfers and, therefore, altruistic migrants may be encouraged to remit more. However, the impact of household size on remittances should be especially strong if there are recently born children in the household that depend on migrants money transfers. These recently born children do not have the option to enter the labor force to provide for themselves and the other members of the household may have to spend more time in childbearing activities limiting their available time for income generating activities. Therefore, in a certain year, at the macro level, the fertility rate may impact the flow of remittances. Hence, in this section we present an estimation in which we used an instrument for remittances. 
The set of instruments that we used is constructed based on the instruments used by Amuedo-Dorantes (2004) and Adams and Page (2005). In order to instrument remittances we used the crop production index, the live stock production index and the rate of DPT (diphtheria, pertussis and tetanus) immunization of the remittance receiving country obtained from the World Development Indicators and the government stability index and political risk index for these countries from the Political Risk Services group (www.prsgroup.com). ${ }^{5}$ Due to data limitations we lose an important chunk of the observations in the instrumental variable estimation. In particular, we are left with only 170 observations. Nevertheless, we think that even with this limitation it is important to show the robustness of our results when we instrument for remittances.

The results of the instrumental variable estimation for the fixed effects approach are presented in Table 4. As it is clear from the table the results are consistent when we used an instrument for remittances. In fact the evidence of a negative impact of remittances on the fertility rate and a positive impact of host country fertility on the home country fertility rate is stronger in the instrumental variable estimation. While in the standard fixed effects estimation the remittances coefficient was negative but not significant, in the instrumental variable estimation the coefficient is negative and significant. We do not show regional instrumental variable estimations due to the limited number of observations that we have for each region.

\section{Conclusions}

Recent decades have witnessed an increase in the flow of workers remittances and a decrease in global fertility rates. In this paper we study the relation between these

\footnotetext{
${ }^{5}$ We tried using several sub-groups of these instruments and the results were generally consistent to the use of different combinations of these variables.
} 
variables. We argue that it is not just money what flows between the host and home country. Migrants typically adopt and later transmit to their families in the home country ideas and norms of behavior from the host country. However, given that the monetary sums that migrants send back home reflect the strength of the bond between the migrant and the household we can use these flows as an indicator of the level of norms transfers. Nevertheless, remittances also affect the budget constraint and expenditure behavior of the receiving households in ways that may ultimately also decrease fertility rates. Previous studies have shown, for instance, that remittances money is usually invested in health expenditures and educational expenses, variables that should affect fertility rates.

In this paper we study the relation between remittances and fertility rates using panel data for a group of 59 countries. We use several econometric specifications like simple OLS, a regression with regional dummies, fixed effects estimation, regional estimations and an instrumental variable estimation in order to test the robustness of our results. In general, results consistently point out to a negative relationship between remittances and fertility rates. This result is quite intuitive if we take into account that most migration takes place from countries with higher fertility rates to countries with lower fertility rates. Therefore, migrants in the host country send ideas about lower fertility targets to their family in the home country. The level of these ideas is captured by the amount of remittances sent. Moreover, as we mentioned above, remittances may increase health expenditures and educational expenses, two factors that may enlarge the fertility reducing aspect of remittances. While results are typically consistent across estimations there seem to be some differences in results for the different specifications for the case of the sub-sample of Asian countries. 
Other factors that seem to affect the fertility rate include the fertility rates of the main five destinations of migrants from a certain country (weighted average). This variable for the most part seems to have a positive effect on fertility, which reinforces the fact that there is a transmission of norms from migrants to their families back home. Some other factors that are already well established in the literature as determinants of fertility such as GDP per capita, female labor force participation and the portion of population in rural areas were also found to be important determinants of fertility in most estimations.

In summary, the results of this paper suggest that migrants send more than money back home, they send values and social norms adopted from the host country. Given that those migrants that remit are more likely to have a strong attachment to the home country, remittances can be a good reflection of the level of ideas that gets transmitted from the host to the home country. It is possible to argue that this transmission of ideas expands to other aspects of household behavior besides fertility choices, such as female labor force participation. That inquiry, however, is left for future research. 


\section{References}

Adams, Richard H. Jr. 2006. Remittances, household expenditure and investment in Guatemala. The World Bank Policy Research Working Paper Series, 3532. Washington, D.C.: The World Bank.

Adams, Richard H. Jr. and Paige, John. 2005. Do International Migration and Remittances Reduce Poverty in Developing Countries? World Development, 33, 16451669.

Amuedo-Dorantes, Ca. and Pozo, S. 2004. Worker's Remittances and the Real Exchange Rate: A Paradox of Gifts. World Development, 32, 1407-1417.

Amuedo-Dorantes, Ca. and Pozo, S. 2006. Migration, Remittances and Male and Female Employment Patterns. American Economic Review 96(2), 222-226.

Amuedo-Dorantes, C., T. Sainz and S. Pozo. 2007. Remittances and Healthcare Expenditure Patterns of Populations in Origin Communities: Evidence from Mexico. Integration \& Trade Journal, 27, 159-184.

Beine, M., Docquier, F. and Schiff, M. 2008. International Migration, Transfers of Norms and Home Country Fertility. IZA-Working Paper No. 3912.

Chami, R., Fullenkamp, C., Jahjah, S. 2005. Are Immigrant Remittance Flows a Source of Capital for Development? IMF-Working Paper 52(1), 55-81

Cleland, J. 2003. Education and future fertility trends, with special reference to midtransitional countries in Completing the Fertility Transition, United Nations Population Division Special Report.

Docquier, F. 2004. Income distribution, non-convexities and the fetility-income relationship. Economica. 71 (282), 261 - 273.

Edwards, A and M. Ureta. 2003. International migration, remittances, and schooling: evidence from El Salvador. Journal of Development Economics, 72, 2, 429-461

El-Sakka, M. and McNabb, R. 1999. The Macroeconomic Determinants of Migrant Remittances. World Development, 27, 1493-1502.

Fargues, P. 2007. The demographic benefit of international migration: a hypothesis and its application to Middle Eastern and North African countries in Ozden, C. and M. Schiff (eds.), International migration, economic development and policy, World Bank and Palgrave Macmillan: Washington, DC.

Fernandez, R. and Fogli, A. 2009. Culture: An Empirical Investigation of Beliefs, Work, and Fertility. American Economics Journal: Macroeconomics, 1, 1, 146 - 177. 
Jones, L., Schoonbroodt, A., Tertilt, M. 2008. An economic history of fertility in the U.S. in Frontiers of Family Economics, ed. By P. Rupert, vol.1 Emerald Press, Forthcoming.

Kulu, H. 2003. Migration and Fertility: Competing Hypotheses Re-examined. Max Planck Institute for Demographic Research, Working Paper 35.

Levitt, P. 1998. Social Remittances: Migration Driven Local-Level Forms of Cultural Diffusion. International Migration Review 32, 926-948.

Lu, Y. and D. Treiman. 2007. The Effect of Labor Migration and Remittances on Children's Education among Blacks in South Africa, California Center for Population Research, On Line Working Paper Series, CCPR-001-07

McKibbin, W. 2006. The Global Macroeconomic Consequences of a Demographic Transition. Asian Economic Papers 5 (1), 92-134.

Parsons, C.R., R. Skeldon, T.L. Walmsley and L.A. Winters. 2007. Quantifying International Migration: A Database of Bilateral Migrant Stocks. World Bank Policy Research Working Paper, No. 4165.

Sleebos, J. 2003. Low Fertility Rates in OECD Countries: Facts and Policy Responses, OECD Social, Employment and Migration Working Papers, 15.

United Nations. 1986. Rural-urban residence and fertility: selected findings from the World Fertility Survey data. Department of International Economic and Social Affairs, Population Division, 1986. vii, 69 p. (ESA/P/WP/95.)

Valero-Gil, J. 2008. Remittances and the Household's Expenditures on Health. Journal of Business Strategy, Forthcoming.

Vargas-Silva, C. 2008. Crime and Remittance Transfers. Eastern Economic Journal, Forthcoming.

World Bank. World Development Indicators www.worldbank.org/data/onlinedatabases.

World Bank. 2008. Remittances Factbook. http://econ.worldbank.org/WBSITE/EXTERNAL/EXTDEC/EXTDECPROSPECTS/0,,c ontentMDK:21352016 pagePK:64165401 piPK:64165026 theSitePK:476883,00.html

Yamada, T. 1984. Causal Relationships Between Infant Mortality and Fertility in Developed and Less Developed Countries. NBER Working Paper No. 1528.

Yamada, T. and Yamada, T. 1984. Married women's labor force participation and fertility in urban Japan. NBER Working Paper No. 1362. 
Figure 1 - Remittances and Fertility Rates Across Regions for Countries in the Sample.

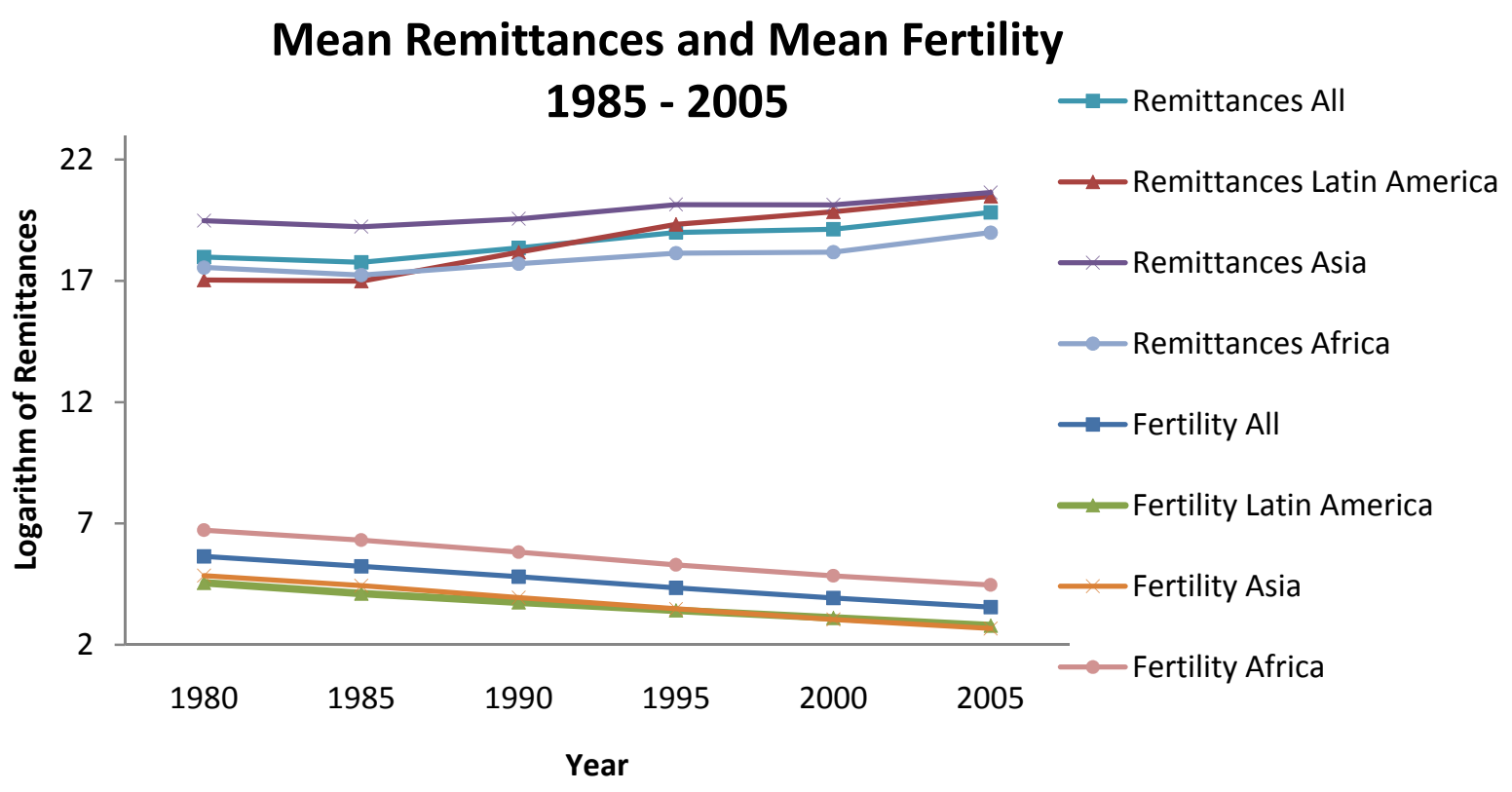


Table 1 - Correlation Coefficients between Log of Remittances and Fertility

\begin{tabular}{lc} 
Sample & Correlation Coefficient \\
\hline Full & -0.46 \\
Latin America & -0.51 \\
Africa & -0.43 \\
Asia & -0.28 \\
\hline
\end{tabular}


Table 2 - Macroeconomic Determinants of Fertility: Full Sample

\begin{tabular}{lccc}
\hline Variable & $(1)$ & $(2)$ & $(3)$ \\
\hline \multirow{2}{*}{ Remittances } & $-0.22^{* * *}$ & $-0.17^{* * *}$ & -0.06 \\
& $(0.03)$ & $(0.02)$ & $(0.05)$ \\
Host Fertility Rate & $0.34^{* * *}$ & $0.26^{* * *}$ & $0.69^{* * *}$ \\
& $(0.04)$ & $(0.05)$ & $(0.13)$ \\
Pop. Rural Areas & $0.01^{*}$ & $0.02^{* * *}$ & $0.07^{* * *}$ \\
& $(0.01)$ & $(0.01)$ & $(0.01)$ \\
Female Labor Force Participation & $-0.02^{* * *}$ & $-0.01^{* * *}$ & $-0.02^{*}$ \\
& $(0.00)$ & $(0.00)$ & $(0.01)$ \\
Income Per Capita & $-0.59^{* * *}$ & $-0.47^{* * *}$ & 0.04 \\
& $(0.09)$ & $(0.10)$ & $(0.28)$ \\
Percentage of Migrants & $0.05^{* * *}$ & $0.06^{* * *}$ & 0.00 \\
& $(0.01)$ & $(0.01)$ & $(0.04)$ \\
Asia Dummy & - & $-0.76^{* * *}$ & - \\
Latin America Dummy & & $(0.17)$ & - \\
$\mathrm{R}^{2}$ & - & $-0.24^{*}$ & \\
& & $(0.15)$ & 0.50 \\
Observations & 0.66 & 0.68 & 343
\end{tabular}

Note: (1) OLS estimation, (2) OLS estimation with regional dummies, (3) fixed effects estimation. Robust standard errors are in parenthesis. *, **, *** indicate $10 \%, 5 \%$ and $1 \%$ level of significance. 
Table 3 - Macroeconomic Determinants of Fertility: Regional Samples

\begin{tabular}{|c|c|c|c|c|c|c|}
\hline \multirow{2}{*}{ Variable } & \multicolumn{2}{|c|}{ Latin America } & \multicolumn{2}{|c|}{ Africa } & \multicolumn{2}{|c|}{ Asia } \\
\hline & $(1)$ & $(2)$ & (3) & $(4)$ & $(5)$ & $(6)$ \\
\hline Remittances & $\begin{array}{c}-0.07 * * \\
(0.04)\end{array}$ & $\begin{array}{c}-0.14^{* * *} \\
(0.04)\end{array}$ & $\begin{array}{c}-0.17 * * * \\
(0.04)\end{array}$ & $\begin{array}{l}-0.17^{*} \\
(0.10)\end{array}$ & $\begin{array}{c}-0.28 * * * \\
(0.07)\end{array}$ & $\begin{array}{c}0.29 * * * \\
(0.08)\end{array}$ \\
\hline Host Fertility Rate & $\begin{array}{c}0.70 * * * \\
(0.19)\end{array}$ & $\begin{array}{c}-0.96 * * \\
(0.42)\end{array}$ & $\begin{array}{c}0.20 * * * \\
(0.04)\end{array}$ & $\begin{array}{c}0.48 * * * \\
(0.16)\end{array}$ & $\begin{array}{c}0.14 \\
(0.16)\end{array}$ & $\begin{array}{c}1.25 * * * \\
(0.13)\end{array}$ \\
\hline Pop. Rural Areas & $\begin{array}{c}0.03^{* * *} \\
(0.01)\end{array}$ & $\begin{array}{c}0.05 * * * \\
(0.02)\end{array}$ & $\begin{array}{c}0.03^{* * *} \\
(0.01)\end{array}$ & $\begin{array}{c}0.08 * * * \\
(0.02)\end{array}$ & $\begin{array}{c}0.00 \\
(0.02)\end{array}$ & $\begin{array}{c}0.08 * * * \\
(0.01)\end{array}$ \\
\hline $\begin{array}{l}\text { Female Labor Force } \\
\text { Participation }\end{array}$ & $\begin{array}{c}-0.03^{* * *} \\
(0.01)\end{array}$ & $\begin{array}{l}-0.03^{*} \\
(0.01)\end{array}$ & $\begin{array}{c}0.00 \\
(0.00)\end{array}$ & $\begin{array}{l}-0.02 \\
(0.04)\end{array}$ & $\begin{array}{c}-0.04 * * * \\
(0.01)\end{array}$ & $\begin{array}{l}-0.03 \\
(0.02)\end{array}$ \\
\hline Income Per Capita & $\begin{array}{l}-0.35 \\
(0.26)\end{array}$ & $\begin{array}{l}-0.04 \\
(0.67)\end{array}$ & $\begin{array}{c}-0.40 * * * \\
(0.11)\end{array}$ & $\begin{array}{l}-0.05 \\
(0.48)\end{array}$ & $\begin{array}{c}-0.64^{* * *} \\
(0.23)\end{array}$ & $\begin{array}{c}0.00 \\
(0.27)\end{array}$ \\
\hline Percentage of Migrants & $\begin{array}{l}-0.04 \\
(0.03)\end{array}$ & $\begin{array}{c}0.07 * * * \\
(0.03)\end{array}$ & $\begin{array}{c}0.01 \\
(0.02)\end{array}$ & $\begin{array}{c}0.01 \\
(0.11)\end{array}$ & $\begin{array}{c}0.03^{* *} \\
(0.02)\end{array}$ & $\begin{array}{l}-0.05 \\
(0.04)\end{array}$ \\
\hline $\mathrm{R}^{2}$ & 0.72 & 0.41 & 0.67 & 0.59 & 0.58 & 0.03 \\
\hline Observations & 80 & 80 & 163 & 163 & 100 & 100 \\
\hline
\end{tabular}

Note: (1), (3), (5) OLS estimation, (2), (4), (6) fixed effects estimation. Robust standard errors are in parenthesis. *, **, *** indicate $10 \%, 5 \%$ and $1 \%$ level of significance. 
Table 4 - Macroeconomic Determinants of Fertility: Instrumental Variable

\begin{tabular}{lcc}
\hline Variable & $(1)$ & $(2)$ \\
\hline Remittances & $-0.54^{* * *}$ & $-0.25^{* * *}$ \\
& $(0.12)$ & $(0.07)$ \\
Host Fertility Rate & $0.24^{* * *}$ & $0.46^{* * *}$ \\
& $(0.08)$ & $(0.13)$ \\
Pop. Rural Areas & 0.00 & $0.07^{* * *}$ \\
& $(0.01)$ & $(0.01)$ \\
Female Labor Force Participation & $-0.02^{* * *}$ & 0.00 \\
& $(0.01)$ & $(0.01)$ \\
Income Per Capita & $-0.75^{* * *}$ & $0.51^{*}$ \\
Percentage of Migrants & $(0.16)$ & $(0.27)$ \\
& $0.04^{* * *}$ & -0.02 \\
$\mathrm{R}^{2}$ & $(0.01)$ & $(0.03)$ \\
Observations & 0.52 & 0.37
\end{tabular}

Note: (1) OLS estimation, (2) fixed effects estimation. Robust standard errors are in parenthesis.

$*$, **, *** indicate $10 \%, 5 \%$ and $1 \%$ level of significance. 


\section{Appendix}

Descriptive Statistics

\begin{tabular}{lcc}
\hline Variable & Mean & St. Dev. \\
\hline Fertility & 4.56 & 1.66 \\
Remittances & $9.46 \mathrm{e}+08$ & $2.45 \mathrm{e}+09$ \\
Host Fertility Rate & 3.26 & 1.64 \\
Pop. Rural Areas & 57.67 & 20.02 \\
Female Labor Force Participation & 50.48 & 18.20 \\
Income Per Capita & 1757.22 & 2294.40 \\
Percentage of Migrants & 3.88 & 7.91 \\
Political Risk Index & 56.92 & 12.11 \\
Government Stability Index & 7.19 & 2.37 \\
DPT & 67.69 & 25.35 \\
Livestock Production Index & 79.79 & 22.30 \\
Crop Production Index & 80.48 & 20.72
\end{tabular}

